\title{
Research Activity in the Czech and Slovak Regions
}

\author{
Vladimír Žítek \\ Faculty of Economics and Administration, Masaryk University, Czech Republic \\ Viktorie Klímová \\ Faculty of Economics and Administration, Masaryk University, Czech Republic
}

\begin{abstract}
Research and development represent an important source for the introduction of new innovation, in particular technical innovation. Individual regions differ considerably in the level of their research activity and in their preconditions for it. The aim of this paper is to compare the level of research activity in Czech and Slovak regions. The analysis is carried out at the NUTS3 regions level; therefore, it involves 14 regions in the Czech Republic and 8 regions in Slovakia. Our analysis is focused on expenditures on R\&D and human resources in R\&D. We analyze the source of financing (public, business), field of science (technical and natural sciences), type of research (basic, applied), and the number of R\&D personnel in full time equivalent. The attention is also paid to the institutions responsible for support of R\&D in both countries. The level of research activity in the Czech Republic is significantly higher than in Slovakia. In both countries the research is concentrated in the capital cities and the South Moravian Region in the case of the Czech Republic. Big differences between capital cities and other regions were observed.
\end{abstract}

Keywords: research, development, innovation, region, Czech Republic, Slovakia JEL classification: O31, R12

\section{Introduction}

Research and development (R\&D) is perceived as an important source for new innovation in enterprises (Coronado et. al., 2008, Breznik, 2014, Barge-Gil et al., 2015). In countries we consider to be the innovation leaders, we can observe a high level of expenditure on research and development (Baćović, 2015). The European Union aims to increase expenditure on R\&D to $3 \%$ of GDP (European Commission, 2010). The highest expenditure on R\&D within the EU member states is to be found in Finland, Sweden, and Denmark. The importance of R\&D and innovation has also been reflected in the cohesion policy, where it represents the first thematic objective for financing from the Structural Funds (Regulation (EU) No 1303/2013).

The role of R\&D in development of innovation is also broadly discussed in scientific literature. In particular, we can mention the concept of national and regional innovation systems, which investigates individual elements of innovation systems and mutual relations among them. Protagonists of this concept analyze for instance R\&D intensity or presence of research organizations and they give recommendations for research and innovation policy (Tödtling et al., 1999, Doloreux, 2002, Freeman, 2002). The more broadly oriented concept of national innovation capacity perceives R\&D as one of the building blocks for innovation ability (Furman et al., 2002). The scientific literature discusses the fact that due to market imperfections companies invest less capital in R\&D. The main reason for this is the existence of market failures (non- 
appropriability, non-divisibility, information asymmetry, and uncertainty), which cause that the equilibrium level of resources allocated to R\&D is lower than the socially optimal level (Weber et al., 2012, Beck et al., 2016, Bronzini et al., 2016). Therefore, one of the aims of research and innovation policy is to alleviate these market failures and to enhance private investments in research, development, and innovation (McCann et al., 2013). Additionally, the innovation systems concept emphasizes the system failures that are related to institutions, coordination, and linkages (Lundvall et al., 2005). Woolthius et al. (2005) categorized them into infrastructure, institutional, interactive, and ability failures.

The paper is structured as follows: Firstly, the research systems in both countries are briefly described. Consequently, we explain the aim of the paper and the methods that we have used. Afterwards, the results are presented.

\section{Support of R\&D in the Czech Republic and Slovakia}

The Czech Republic (CR) and Slovakia constituted one national state called Czechoslovakia till 1992. Both countries have many common features and they have similar historical, social, cultural, and economic characteristics. Both countries cooperate intensively in economic, educational and research fields. Due to shared history they have a similar research supportive system. Important roles are played by the Ministries of Education, but the role of the Slovak Ministry is slightly more complex. Furthermore, a new Ministry of Science will be established in the Czech Republic in 2017. The CR has one supporting agency specialized in basic research (Czech Science Foundation GACR, founded in 1993) and another one specialized in applied research (Technology Agency TACR, founded in 2010). Both of them were established by the act on support of R\&D and they are fully independent of the Ministry of Education. In Slovakia, basic as well as applied research are supported by the Slovak Research and Development Agency SRDA (founded in 2005), which is financed through the Ministry of Education. Additionally, this Ministry has established the Scientific Grant Agency VEGA and internal Cultural and Educational Grant Agency KEGA. Both Ministries of Education play the role of the managing authorities of operational programs that support R\&D from the European Structural Funds. Furthermore, the Slovak Ministry has established the Research Agency which has the function of an intermediate body for the operational program. Besides universities, the public basic research is conducted by Academies of Science in both countries.

\section{Aim and methods}

The aim of our paper is to assess and compare the research activity in the CR and Slovakia. The evaluation is carried out at the level of NUTS 3 regions (i.e., 14 regions in the $C R$ and 8 regions in Slovakia). These regions represent self-governing territorial units, i.e., elements existing between national states and municipalities. In order to be able to compare the regions it is necessary to design appropriate indicators first.

Consequently, values of these variables have to be normalized, because they are expressed in various units. The normalization formula is:

$$
x^{\prime}=\frac{x-m}{\sigma}
$$

where the sign of the centered value $x-m$ represents an above-average or $a$ below-average value of the i-th value of $x$; the normalized value says by how many standard deviations $(\sigma)$ the value $x$ is deflected above/below the average. If all indicators have the same weight, the normalized values have to be rescaled (Nardo et al., 2005): 


$$
x=\frac{x-\min (x)}{\max (x)-\min (x)}
$$

The rescaled values of indicators can be used for cluster analysis. Through this analysis we can group the regions into clusters based on their similarity. The nonhierarchical method of k-means with Euclidean distance is used.

\section{Results}

Five indicators have been selected for the evaluation of regional R\&D activity in the CR and Slovakia. These indicators represent various aspects of R\&D. The indicators are as follows:

- EMP: the number of R\&D personnel in full time equivalent (FTE) per 1000 employees in regional economy,

- RDE: the total expenditure on R\&D expressed as a share of regional GDP (\%),

- BAS: the share of basic research expenditures in the current R\&D expenditures (\%),

- NTS: the share of expenditures on natural and technological sciences in the total R\&D expenditures (\%),

- BEE: the share of business expenditures in the total R\&D expenditures (\%).

We used statistical data for 2014 published by the Czech Statistical Office (CZSO) and Statistical Office of Slovak Republic (SOSR). Table 1 shows the values of the indicators.

As regards indicators expressing the share of expenditures on basic research, natural and technological sciences, and business expenditures, they reflect the structure of research organizations and tradition of R\&D in the regions. If public research institutes and public universities are present in the region, the share of basic research as well as public resources is usually higher. The natural and technological sciences dominate in most of the regions; however, their proportion is differentiated. It depends on the tradition of other fields; in particular, e.g. agricultural sciences prevail in the Nitra Region. 
Table 1

R\&D characteristics in the Czech and Slovak Regions in 2014

\begin{tabular}{lrrrrr}
\hline Region & $\begin{array}{r}\text { EMP } \\
\text { (number) }\end{array}$ & \multicolumn{1}{c}{$\begin{array}{l}\text { RDE } \\
(\%)\end{array}$} & \multicolumn{1}{c}{$\begin{array}{l}\text { BAS } \\
(\%)\end{array}$} & NTS $(\%)$ & \multicolumn{1}{l}{ BEE } \\
\hline Prague (CZ010) & 36.03 & 2.86 & 43.97 & 75.12 & 37.15 \\
\hline Central Bohemian (CZ020) & 8.81 & 2.01 & 10.53 & 96.39 & 74.42 \\
\hline South Bohemian (CZ031) & 7.34 & 1.14 & 38.47 & 85.87 & 55.32 \\
\hline Pilsen (CZ032) & 11.39 & 2.15 & 16.20 & 89.26 & 56.56 \\
\hline Karlovy Vary (CZ041) & 1.12 & 0.18 & 3.66 & 99.20 & 93.98 \\
\hline Usti (CZ042) & 3.04 & 0.48 & 19.70 & 77.73 & 52.26 \\
\hline Liberec (CZ051) & 10.49 & 1.89 & 13.74 & 98.31 & 64.07 \\
\hline Hradec Kralove (CZ052) & 7.01 & 1.04 & 13.98 & 58.13 & 51.26 \\
\hline Pardubice (CZ053) & 10.47 & 1.61 & 16.67 & 94.57 & 72.05 \\
\hline Vysocina (CZ063) & 4.17 & 0.88 & 5.37 & 98.33 & 85.44 \\
\hline South Moravian (CZ064) & 21.60 & 3.66 & 31.48 & 81.60 & 47.39 \\
\hline Olomouc (CZ071) & 11.04 & 1.69 & 49.71 & 64.45 & 40.55 \\
\hline Zlin (CZ072) & 7.05 & 1.29 & 8.46 & 93.18 & 65.50 \\
\hline Moravian-Silesian (CZ080) & 7.80 & 1.26 & 36.54 & 91.22 & 58.24 \\
\hline Bratislava (SK010) & 26.10 & 1.48 & 52.27 & 65.11 & 31.73 \\
\hline Trnava (SK021) & 3.90 & 0.56 & 46.05 & 79.75 & 28.80 \\
\hline Trencin (SK022) & 4.12 & 0.78 & 10.73 & 97.89 & 59.88 \\
\hline Nitra (SK023) & 5.15 & 0.64 & 35.98 & 20.67 & 21.07 \\
\hline Zilina (SK031) & 4.30 & 0.93 & 24.24 & 70.77 & 33.83 \\
\hline Banska Bystrica (SK032) & 4.67 & 0.53 & 34.90 & 70.09 & 35.08 \\
\hline Presov (SK041) & 2.09 & 0.35 & 29.05 & 84.76 & 38.06 \\
\hline Kosice (SK042) & 7.67 & 0.75 & 75.83 & 60.24 & 16.81 \\
\hline
\end{tabular}

Source: CZSO $(2015 b, 2016), \operatorname{SOSR}(2015,2016)$, authors' own calculations

Figure 1

The number of R\&D personnel in full time equivalent (FTE) per 1000 employees in the Czech and Slovak Regions (2014)

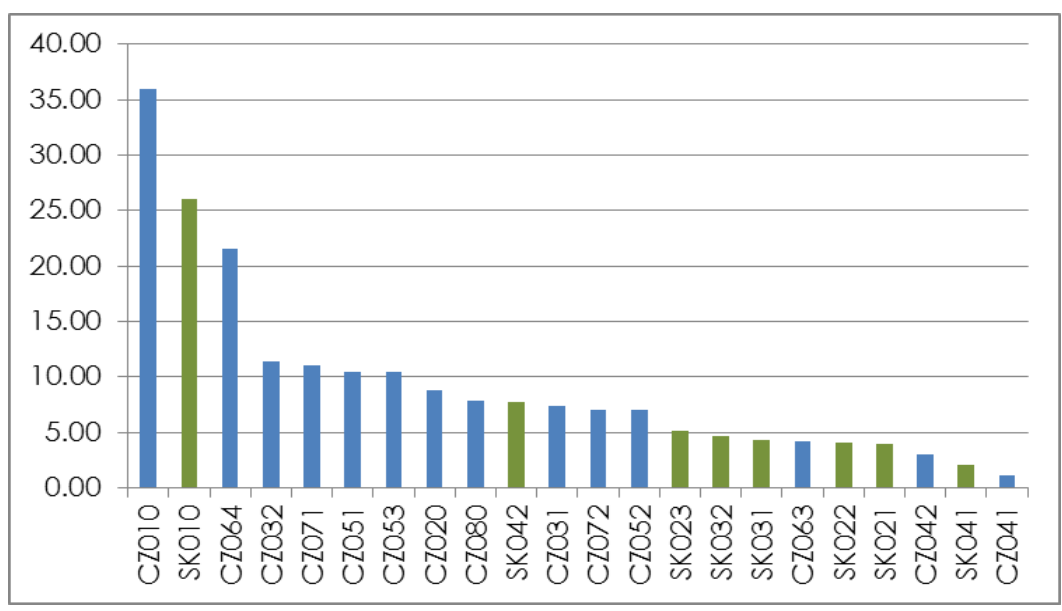

Source: CZSO $(2015 b, 2016), \operatorname{SOSR}(2015,2016)$, authors' own calculations 
Research and development can be characterized by highly qualified employees, both researches and other personnel. Their number in full time equivalent reflects the importance of R\&D in the region. Figure 1 shows that the highest number of personnel is in Prague (CZO10). With a gap it is followed by the Bratislava (SKO10) and South Moravian (CZO64) Regions. Fewer than 5 persons in R\&D per 1000 employees were identified in 8 regions, the lowest numbers were observed in the Presov (SK041) and Karlovy Vary (CZO41) Regions.

The total expenditures on R\&D expressed as a share of GDP (in \%) are commonly used for interregional comparisons. Expenditures on R\&D are considered to be an important prerequisite for competitiveness increase; therefore, there is a natural requirement for their sufficient volume. The South Moravian Region dominates considerably in the ranking of the Czech and Slovak regions. This is particularly caused by the support from the cohesion policy. This region is followed by Prague, the Pilsen and Central Bohemian Regions (their expenditures exceed $2 \%$ of GDP). The highest values within the Slovak regions were observed in the Bratislava (1.48 \%) and Zilina (0.93\%) regions. Figure 2 shows the positions of individual regions.

Figure 2

The total expenditures on R\&D expressed as a share (in \%) of GDP in the Czech and Slovak Regions (2014)

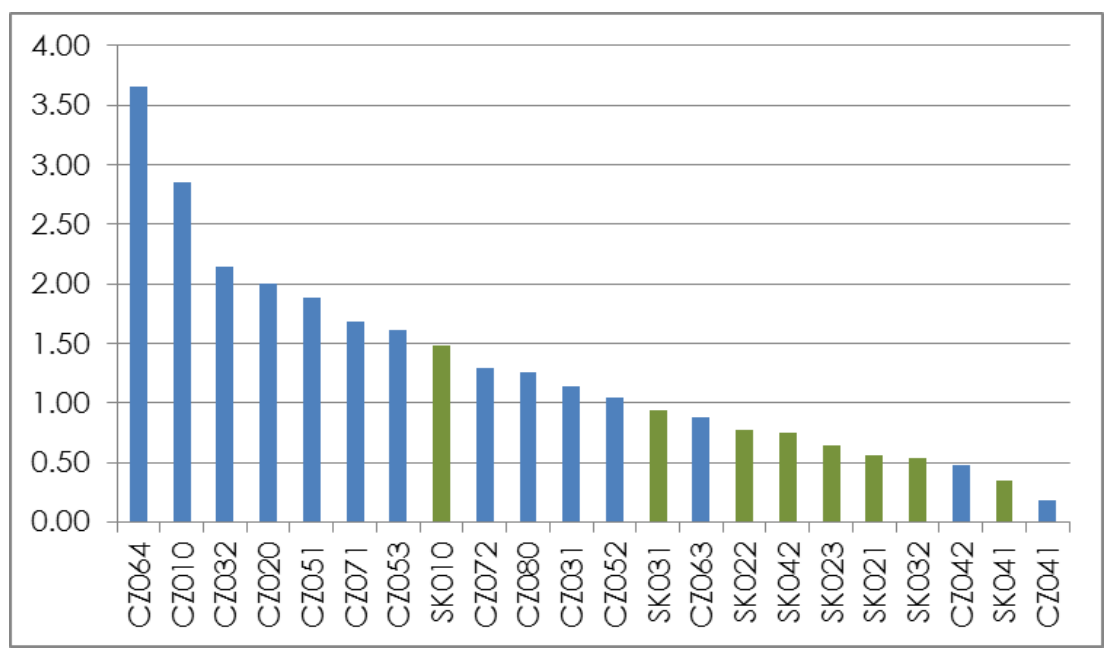

Source: CZSO $(2015 b, 2016)$, SOSR $(2015,2016)$, authors' own calculations

In accordance with the above mentioned methodology, the values of the selected indicators were normalized into dimensionless numbers and then rescaled to take values between zero and one $(0$ is the minimum value, 1 is the maximum value - see table 2).

The rescaled values are suitable as input data for cluster analysis. When the method of k-means is used, the key step is to set the appropriate number of clusters. With respect to the number of regions, number of variables and number of indicators, the number of clusters is set to $k=6$ :

- $\quad 1^{\text {st }}$ Cluster - Capital city Prague, the South-Moravian, and Bratislava Regions,

- $2^{\text {nd }}$ cluster - the Usti, Hradec Kralove, Trnava, Zilina, BanskaBystrica, and Presov Regions,

- $3^{\text {rd }}$ cluster - the Nitra and Kosice Regions,

- $4^{\text {th }}$ Cluster - the South-Bohemian, Olomouc, and Moravian-Silesian Regions, 
- $5^{\text {th }}$ cluster - the Central Bohemian, Pilsen, Liberec, Pardubice, Zlin, and Trencin Regions,

- $6^{\text {th }}$ cluster - the Karlovy Vary, and Vysocina Regions.

Table 2

Normalized and rescaled values of R\&D in the Czech and Slovak Regions (2014)

\begin{tabular}{lccccc|cccccc}
\hline Region & EMP & RDE & BAS & NTS & BEE & Region & EMP & RDE & BAS & NTS & BEE \\
\hline CZ010 & 1.00 & 0.77 & 0.56 & 0.69 & 0.26 & CZ071 & 0.28 & 0.43 & 0.64 & 0.56 & 0.31 \\
\hline CZ020 & 0.22 & 0.53 & 0.10 & 0.96 & 0.75 & CZ072 & 0.17 & 0.32 & 0.07 & 0.92 & 0.63 \\
\hline CZ031 & 0.18 & 0.28 & 0.48 & 0.83 & 0.50 & CZ080 & 0.19 & 0.31 & 0.46 & 0.90 & 0.54 \\
\hline CZ032 & 0.29 & 0.57 & 0.17 & 0.87 & 0.52 & SK010 & 0.72 & 0.37 & 0.67 & 0.57 & 0.19 \\
\hline CZ041 & 0.00 & 0.00 & 0.00 & 1.00 & 1.00 & SK021 & 0.08 & 0.11 & 0.59 & 0.75 & 0.16 \\
\hline CZ042 & 0.06 & 0.08 & 0.22 & 0.73 & 0.46 & SK022 & 0.09 & 0.17 & 0.10 & 0.98 & 0.56 \\
\hline CZ051 & 0.27 & 0.49 & 0.14 & 0.99 & 0.61 & SK023 & 0.12 & 0.13 & 0.45 & 0.00 & 0.06 \\
\hline CZ052 & 0.17 & 0.25 & 0.14 & 0.48 & 0.45 & SK031 & 0.09 & 0.22 & 0.29 & 0.64 & 0.22 \\
\hline CZ053 & 0.27 & 0.41 & 0.18 & 0.94 & 0.72 & SK032 & 0.10 & 0.10 & 0.43 & 0.63 & 0.24 \\
\hline CZ063 & 0.09 & 0.20 & 0.02 & 0.99 & 0.89 & SK041 & 0.03 & 0.05 & 0.35 & 0.82 & 0.28 \\
\hline CZ064 & 0.59 & 1.00 & 0.39 & 0.78 & 0.40 & SK042 & 0.19 & 0.16 & 1.00 & 0.50 & 0.00 \\
\hline
\end{tabular}

Source: CZSO $(2015 b, 2016)$, SOSR $(2015,2016)$, authors' own calculations

Based on the cluster analysis the regions are divided into several groups by their mutual similarity. In general and briefly, they can be characterized in this way:

The regions in the $1^{\text {st }}$ cluster have the highest values of EMP and RDE indicators; they have a high share of basic research, an average NTS indicator and a rather lower share of business expenditures.

The regions in the $2^{\text {nd }}$ cluster have insignificant values of all indicators; they do not significantly deviate from any investigated indicator.

The regions in the $3^{\text {rd }}$ cluster are similar to the previous. Values of EMP indicator are slightly higher, but the difference has a rather statistical character. Only the Slovak regions are in this cluster.

The regions in the $4^{\text {th }}$ cluster reach relatively higher values of EMP indicators, expenditures on R\&D exceed $1 \%$ of GDP, the share of natural and technological sciences is above-average and business expenditures represent more than $50 \%$ of resources. This cluster only contains the Czech regions.

The regions in the $5^{\text {th }}$ cluster have higher values of EMP and RDE indicators, share of NTS exceeds $90 \%$ and share of business resources varies between 55 and $70 \%$.

The regions in the $6^{\text {th }}$ cluster can be characterized by a low share of basic research, share of NTS and business expenditures are close to $100 \%$. This situation is given by the fact that no public universities and research institutes are present in these regions.

\section{Conclusions}

The article compares research activity in the regions of the Czech Republic and Slovakia. Both states have common history and similar socio-economic conditions. This provides a suitable basis for their mutual comparison. The expenditures on R\&D in the Czech Republic (2 \% of GDP, i.e., 294 EUR per capita) are higher than in Slovakia (0.89\% of GDP, i.e., 124 EUR per capita) (CZSO, 2015a). This is also reflected in the aims which the states would like to reach in 2020 . While the CR is planning to invest $2.7 \%$ of GDP into R\&D, Slovakia wants to spend $1 \%$ of GDP. 
As we assumed, it was confirmed that in both countries research activity is concentrated in the capital cities and Brno (capital of the South Moravian Region). The absolutely highest expenditures on R\&D were observed in the South Moravian Region. This is caused by the support from the Structural Funds in the framework of cohesion policy. By contrast, Prague and Bratislava have limited access to the Structural Funds.

Our analysis pointed out the fact that research activity is lower in Slovakia than in the CR, which does not represent good conditions for Slovak competitiveness. In our opinion, the Slovak R\&D supporting system is less arranged (clear). Slovakia has no institution specialized in support of applied research. In the Czech Republic the Technology Agency has been established for this purpose. It allows concentrating resources for applied research and paying more attention to cooperation between the research and the business spheres. On the other hand, the Czech research system also has a lot of weaknesses. The level of investments in R\&D is not sufficient, the research environment is often changed by the government, the level of innovation cooperation is low and invested resources do not bring adequate economic effects.

Based on the cluster analysis, the regions were divided into six groups based on their similarities. The $1^{\text {st }}$ cluster contains regions with a high level of research activity. The $6^{\text {th }}$ cluster consists of Czech regions with a low level of research, which is given bythe absence of public universities and research institutes. With respect to this, the Slovak regions are different, because in all Slovak regions we can find at least one public university.

We are aware of the fact that our research has limitations and presents challenges for future research at the same time. We have analyzed data for a oneyear period. In future we would like to make time series which will be more conclusive. The structure of R\&D in both countries is influenced by history, tradition, and presence of big universities. We find the role of public aid to be quite interesting, so future research should investigate the impact of public aid on research and innovation outcomes.

\section{References}

1. Baćović, M. (2015), "Innovation and Economic Growth", in Baćović, M., Milković, M., Pejić-Bach, M., Peković, S. (Eds.), Proceedings of the ENTRENOVA ENTerpriseREsearchInNOVAtion Conference, IRENET', Zagreb, pp. 1-2.

2. Barge-Gil, A., Lopez, A. (2015), „R versus D: Estimating the Differentiated Effect of Research and Development on Innovation Results", Industrial and Corporate Change, Vol. 24 No. 1, pp. 93-129.

3. Beck, M., Lopes-Bento, C., Schenker-Wicki, A. (2016), „Radical or incremental: Where does R\&D policy hit? ", Research policy, Vol. 45 No. 4, pp. 869-883.

4. Breznik, L. (2014), „Deploying Innovation Capability and Its Relevant Sources as a Key to Success: Insights from Slovenian IT firms", Naše gospodarstvo/Our economy, Vol. 60 No. 1-2, pp. 12-25.

5. Bronzini, R., Piselli, P. (2016), "The impact of R\&D subsidies on firm innovation", Research Policy, Vol. 45 No. 2, pp. 442-457.

6. Coronado, D., Acosta, M., Fernández, A. (2008), "Attitudes to innovation in peripheral economic regions", Research Policy, Vol. 37 No. 6, pp. 1009-1021.

7. CZSO. (2015a), "Research and development indicators for the Czech Republic 2014", available at: www.czso.cz (10 January 2016).

8. CZSO. (2015b), "Statistical yearbooks of the Czech regions 2015", available at: WWW.CzSO.cz (1/10/2016).

9. CZSO. (2016), "Research and development indicators of the Czech Regions 20052014", available at: www.czso.cz (2/15/2016). 
10. Doloreux, D. (2002), "What we should know about regional systems of innovation", Technology in Society, Vol. 24 No. 3, pp. 243-263.

11. European Commission. (2010), "Europe 2020. A strategy for smart, sustainable and inclusive growth", available at: http://ec.europa.eu/europe2020/index_en.htm (15 November 2015)

12. Freeman, C. (2002), "Continental, national and sub-national innovation systems complementarity and economic growth", Research policy, Vol. 31 No. 2, pp.191-211.

13. Furman, J. L., Porter, M. E., Stern, S. (2002), "The determinants of national innovative capacity", Research policy, Vol. 31 No. 6, pp. 899-933.

14. Lundvall, B. Å., Borrás, S. (2005), "Science, Technology and Innovation Policy", Fagerberg, J., Mowery, D.C., Nelson, R.R. (Eds.), The Oxford Handbook of Innovation, Oxford University Press, pp. 599-631.

15. McCann, P., Ortega-Argilés, R. (2013), "Modern regional innovation policy", Cambridge Journal of Regions, Economy and Society, Vol. 6 No. 2, pp. 187-216.

16. Nardo, M., Saisana, M., Saltelli, A., Tarantola, S. (2005), Tools for Composite Indicators Building, European Commission - Joint Research Centre, Ispra.

17. Regulation (EU) No $1303 / 2013$ of the European Parliament and of the Council of 17 December 2013.

18. SOSR. (2015), Yearbook of science and technology in the Slovak Republic 2015, Statistical Office of Slovak Republic, Bratislava.

19. SOSR.(2016), Regional Statistical Yearbook of Slovakia 2015, Statistical Office of Slovak Republic, Bratislava.

20. Tödtling, F., Kaufmann, A. (1999), „Innovation systems in regions of Europe - A comparative perspective", European Planning Studies, Vol. 7 No. 6, pp. 699-717.

21. Weber, K. M., Rohracher, H. (2012), „Legitimizing research, technology and innovation policies for transformative change", Research Policy, Vol. 41 No. 6, pp. 1037-1047.

22. Woolthuis, R. K., Lankhuizen, M., Gilsing, V. (2005), "A system failure framework for innovation policy design", Technovation, Vol. 25 No. 6, pp. 609-619.

\section{About the authors}

Vladimír Žítek works as an associate professor atFaculty of Economics and Administration, Masaryk University. His research activities involve the investigations of the regional economy and regional development; he specializes in the issues of the functioning of regional innovation systems, evaluation of the innovation potential, and enhancement of the regional competitiveness in the context of the regional innovation policy. The author can be contacted at zitek@econ.muni.cz.

Viktorie Klímová works as an assistant professor at Faculty of Economics and Administration, Masaryk University. Her research activities involve the issues of regional economy and regional development, she specializes in the institutional and program support for SMEs, with an emphasis on innovative companies, the area of the creation and dissemination of innovation, and the impacts of the regional innovation policy implementation. The author can be contacted at klimova@econ.muni.cz. 